\title{
Language attitudes in the second language situation ${ }^{1}$
}

\section{Riana Roos}

A distinction is made between attitudes and specifically language attitudes. The process of acculturation is dealt with and its influence upon the motivation of ESL leamers. Integrational and instrumental motivation are defined. Teachers' language attitudes, the dangers of prejudice and stereotyping are discussed. Attitude changes are analysed as well as the teacher's role in effecting them.

'n Onderskeid word getref tussen algemene houdings en houdings ten opsigte van taal. Die proses van akkulturasie word behandel, asook die invloed daarvan op die motivering van Engels Tweede Taal-leerders. Die skrywer onderskei verder tussen integrerende en instrumentale motivering. Die onderwysers se houding teenoor die taal word ook bespreek, asook die gevare van bevooroordeeldheid en stereotipering. Veranderinge in houdings word ontleed, en veral die rol wat die onderwyser speel om dié veranderinge teweeg te bring.

The measuring of attitudes has an important role to play in the social sciences. The aim of such measuring is often to draw a profile of a society in order to make certain predictions. Attitude measuring enables the sociolinguist to identify stereotypes regarding language groups and to monitor the results of language planning projects.

Studies of language attitudes make it clear that language cannot be separated from society. Webb (1979) remarks that a person usually transfers his attitude towards a group of people to that group's dialect or language. A complex set of attitudes is formed which could have an influence on language in the teaching situation.

In this essay I will point to a few aspects of attitudes and language attitudes, the implications there of for the teaching situation and the possibility of attitude change.

\section{2}

'ATTITUDES' AND 'LANGUAGE ATTITUDES'

In social psychology an attitude is defined as 'an overall, learned, core disposition that guides a person's thoughts, feelings and actions toward specific others and objects' (Middlebrook, 1980: 157). Our attitudes determine what we attend to in our environment, how we code information regarding the objects in our environment and how we behave towards the objects. An attitude has three components: a cognitive component (beliefs), an affective component (emotions) and a connative (behavioural)

1 This article is based on a paper that was read at a TESOL Conference, University of Pittsburgh (Pennsylvania), August 1989. 
component. Should a change occur in one of the components, it could cause tension in the other two components, which might bring about an attitude change.

It is important to understand the difference between an attitude and an opinion. An attitude is part of the subconscious and would usually not be revealed by direct questions. An opinion is the conscious expression of a belief and is often not a true reflection of the attitude, since the opinion could be influenced by several situational factors. This very fact makes attitude measuring even more difficult, because indirect methods and questions must be devised to reveal attitudes, not opinions.

A language attitude is more than an attitude towards the language only since the language attitude reflects the attitude towards the particular cultural group. According to Webb (1979), language is the most important social polarising factor amongst white South Africans. Because of the close relationship between language and society, it is evident that language attitudes could influence the learning of a second or foreign language. Language is such an integral part of culture and group identity that the learning of a second language could lead to confusion of a person's world view, identity, thinking patterns, emotions and communication. Brown (1987: 128) stresses the fact that language learning is part of a process of acculturation which requires a re-orientation and permeable, adaptable ego boundaries. Because a language attitude is part of such a complex set of attitudes, it usually strongly resists change.

A stereotype is part of the cognitive component of an attitude and is formed by personal experience, one's own emotional needs and by what one is told by others. Although stereotypes are often overgeneralized or false beliefs, they influence the way the individual decodes and interprets information about other individuals or groups. We do not first see, then define; we first define and then see. Information that is consistent with stereotypes is more readily accepted than information that questions their validity.

Stereotypes are usually part of language attitudes and could become obstacles in the way of language learning since one tends to categorize persons according to their accent and pronunciation, even without consciously associating them with certain reference groups.

Gordon Allport's statement regarding stereotyping and labelling is relevant in this context: 'Most people are unaware of this basic law of language - that every label applied to a person refers only properly to one aspect of his nature ... . A category, once formed ..., tends to attract more attributes than it should ... . But our cognitive process is not cautious. The labeled (sic) category includes indiscriminately the defining attribute, probable attributes and wholly fanciful, nonexistent attributes' (Eschholz, 1982: 210).

The social context of language evaluation is very important because language is the main instrument through which social interaction takes place. According to Ryan and Giles (1982) there are three possible points of view from which language could be evaluated. Language evaluation could either reflect intrinsic linguistic inferiorities or superiorities, intrinsic aesthetic differences or social values and preferences.

The first possibility is refuted because of empirical evidence that all languages and varieties of language are linguistically equal. No proof exists to support the notion of greater aesthetic beauty in any specific language. Judgements regarding the quality and prestige of certain language varieties depend upon knowledge of the social connotations of a variety for its speakers. 


\subsection{Techniques}

Semantic differential scales, observation, questionnaires and interviews are used to assess attitudes. A technique that is widely used for the assessment of language attitudes is the so-called 'matched guise' technique.

\subsection{Results and implications of studies of students' language attitudes}

Studies of students' language attitudes provide insight into the importance of language as symbol of membership of a certain cultural or ethnic group. Trudgill (1983) points out that language is a crucial factor that determines group identification and solidarity and leads to greater emphasis on differences between two or more language varieties when one language group is threatened by another. Teachers should be aware of the influence of the wider social situation upon language learning and teaching.

Research was done to find whether a correlation exists between language attitudes, performance in the second language, perseverance and class behaviour.

Some researchers (e.g. Bartley, 1970) found that students who have positive attitudes towards the target language tend to have more perseverance, do not drop the language learning course easily and also participate more freely in the class situation.

Language attitudes could play an important role in the motivation of second language learners. When ESL learners are integrationally motivated, i.e. when they are interested in learning about the English speaking community, they tend to become more proficient in English than learners who are instrumentally motivated, i.e. learners who have to learn the language for some functional purpose only (to pass an examination, for instance). In the multicultural South Africa context teachers should be aware of the fact that many ESL students are instrumentally motivated; they want to learn English in order to study further, to qualify for certain jobs and to gain access to the international community. If teachers could stimulate the interest of their students in the Englishspeaking cultural community, the students' proficiency in English might improve.

The above findings support the view that the learning of a second language is part of a greater acculturation process. Berry (1980) decribes four modes of acculturation, two of which are relevant here. He suggests that integration involves identifying with the other community while still valuing and retaining one's own cultural and ethnic heritage. Assimilation is in my opinion not as healthy a mode of acculturation because it involves identifying with the second language community while rejecting one's own. Berry's idea of integration (like Lambert's [1974] concept of additive bilingualism) implies that a second language learner can develop a high level of proficiency in the target language while maintaining his own cultural identity.

Teachers of second or foreign languages should guard against treatment of second language acquisition as involving identification with one group as opposed to another. Should a student experience the learning of the target language as a threat to his ethnic or cultural identity, his motivation to learn the language could feel aversion towards the language learning situation and towards the target language itself. The standard dialect that is taught could symbolize social values that oppose the values of the student. A student might resist the social values associated with the target language to such an extent that his learning of the target language could be impaired.

Some researchers propose that learning a second language could change the learner's attitude towards that language. According to them, success in the learning of the second language could lead to identification with that language community, which could lead to change of the language attitude in a positive direction. Other studies did not render similar results. Proof does exist, however, that contact with mother tongue speakers of 
the target language in an enjoyable, relaxed atmosphere could lead to positive change in the language attitude and to diminished anxiety in the class situation.

Gardner (1988) suggests that it is probable that, just as attitudes and motivation influence second language acquisition, so could second language acquisition influence attitudes and motivation. Several studies have suggested that

individuals' attitudes toward the other language community and the language learning situation, and their level of motivation, among other things, will influence their relative degree of success in learning the other language. It is equally reasonable, however, that happy experiences in language learning situations and success in learning the language will foster positive attitudes and enhance motivation, while negative experiences and/or failure to do well could engender negative attitudes and loss of motivation (Gardner 1988: 137).

Krashen's (1981) monitor model suggests that attitudes and motivation form part of a student's 'affective filter' that influences the extent to which material presented to the second language learner becomes input that contributes to the acquisition process. Research has also demonstrated (Gardner et al., 1987) that attitudes and motivation influence the retention of second language material largely because they affect the extent to which individuals make use of the language after completion of the course.

Whatever the exact influence of attitudes and motivation might be, fact remains that second language learning is a dynamic process in which all of the above causal variables (and others) should be taken into account.

\subsection{Results and implications of studies of teachers' language attitudes}

Teachers are not and cannot be objective filters through which language teaching takes place. Teachers have attitudes towards language varieties and culture groups and judge the language usage of students (often subconsciously) on these grounds.

Stereotyping plays an important role in teachers' judgements of students' language usage and proficiency. Rosenthal and Jacobson (1968) found that teachers' expectations could be manipulated by providing them with false information about the language proficiency of the students. Williams (1974) found that teachers judge students' oral language use on only two semantic differential scales, namely 'confidence - eagerness' and 'ethnicity non-standardness' (Fasold 1984). Stereotyped expectations regarding the students' way of expression and presentation often form the basis of teachers' judgements of the students' language proficiency.

If the teacher is unaware of the fact that he/she is prejudiced towards speakers of certain language varieties, the students' language learning process could be influenced negatively. This could be even worse if the teacher holds the linguistically unfounded opinion that speakers of 'non-standard' varieties are less intelligent than speakers of 'standard' varieties.

Such subjective judgement on the teacher's side could also have a negative influence on the performance of the student. According to the 'self-fulfilling prophecy', people often behave as others expect them to behave. Middlebrook stresses the fact that 'if you are set to see a particular behavior (sic) in someone else, you may - in subtle ways - act so that the other person's behavior (sic) meets your expectations' (1980:171). This kind of situation perpetuates the existence of stereotypes. If a student becomes aware of the fact that his language variety is seen as inferior, he might adjust his performance and his perception of his own abilities to suit his teacher's negative perceptions and expectations. 
'To change attitudes based on personal experience and social sources, the basic tactic is to introduce information that is inconsistent with the individual's present attitudes and then make it difficult for the individual to dismiss the material' (Middlebrook, 1980: 198). Because stereotypes help people to organize and handle their worlds, they are not easily changed. A change in one of the three components of an attitude could exert pressure on the other two components of an attitude to change too. Evidence that opposes a certain belief calls for change in the cognitive component of an attitude. Should a person find that one of his beliefs is based upon incorrect or imcomplete evidence, changes might take place in his emotions and behaviour too.

The so-called 'foot-in-the-door technique' could also be used in the language teaching situation to change teachers' language attitudes. If teachers are confronted with evidence of stereotyped judgements on their sides and could be persuaded to commit themselves publicly to a more positive attitude, dissonance exists within the language attitude. The teachers might now try to behave according to their new opinions. So much tension could be caused within the attitude that the emotional component could also change in accordance with the cognitive and behavioural components.

Language attitudes form part of one's ethnic and personal identity, which consists of a system of interrelated attitudes. An attack on any one attitude in this interrelated structure would threaten the whole structure and thus produce an especially high level of resistance' (Middlebrook 1980: 226). If an attempt is made to change the language attitudes of a group or an individual, care should be taken not to offend the target group. An insensitive attempt to change a language attitude might polarize the initial attitude and reinforce the stereotype.

Several studies in social psychology have proved that face to face persuasion is more effective than persuasion via the media (Middlebrook, 1980). This implies that the teacher, if he is a native speaker of the target language, could influence students' language attitudes. He should also create opportunities for his students to communicate with mother tongue speakers of the target language in a relaxed social situation. Personal contact might provide the necessary evidence to overcome stereotypes towards linguistic and culture groups.

\section{CONCLUSION}

Many writers have expressed the opinion that language attitudes cannot be changed (Webb, 1979). Others feel more positive about the possibility of such changes: 'the teacher needs to be aware that everyone has both positive and negative attitudes. The negative attitudes can be changed' (Brown, 1987: 127). Personal contact between teacher and student could provide the evidence to change stereotypes about language varieties and cultural groups.

Teachers should be encouraged to have an attitude of acceptance of 'non-standard' language varieties and speakers of such varieties. Of course it would be difficult to bring about such an acute attitude change since such acceptance opposes the more rigid didactics of language teaching that is taught to teacher students and that aims at producing an identical group of speakers.

If students experience problems in the learning situation because they speak 'nonstandard' varieties of language, those problems are due to the negative attitudes of society towards 'non-standard' language. Trudgill (1983) suggests that teachers should teach students to read the 'standard' language but that teachers and the rest of society should be educated to understand, tolerate and appreciate 'non-standard' varieties as complex, sufficient and equivalent linguistic systems. Though this might seem to be an 
unattainable goal, a widespread community education programme might yield positive results.

In this massive task the linguist, social psychologist and language teacher could perform key roles.

Teachers can aid in disspelling what are often myths about other cultures, and replace those myths with a realistic understanding of the other culture as one that is different from one's own, yet to be respected and valued. Learners can thus move through the hierarchy of affectivity ... through awareness and responding, to valuing, and finally to an organized and systematic understanding and appreciation of the foreign culture (Brown, 1987: 127).

\section{REFERENCES}

BROWN, H.D. 1987. Principles of language learning and teaching. New Jersey: PrenticeHall.

EDWARDS, J.R. 1984. Language and disadvantage. London: Edward Arnold.

ESCHHOLZ, P., A. Rosa and V. Clark (Eds.). 1982. Language awareness. New York: St. Martin's Press.

FASOLD, R. 1984. The sociolinguistics of society. Oxford: Basil Blackwell.

GARDNER, R.C. 1988. Attitudes and motivation. In: Annual review of applied linguistics, 9, 135-148.

KRASHEN, S.D. 1981. Second language acquisition and second language learning. Oxford: Pergamon Press.

LAMBERT, W.E. 1974. Cultural and language as factors in learning and education. In: Aboud, F.E. \& R.D. Meade (Eds.). The fifth Western symposium on learning: Cultural factors in learning and education, 91-122. Bellingham: Western Washington State College.

MIDDLEBROOK, P.N. 1980. Social psychology and modern life. New York: Alfred Knopf.

RYAN, E.B. AND S.W. OLDS. 1985. Attitudes towards language variation. London: Edward Arnold.

TRUDGILL, P. 1983. Sociolinguistics: An introduction to language and society. Middlesex: Penguin.

VORSTER, J. AND L. PROCTOR. 1976. Black attitudes to 'white' languages in South Africa: a pilot study. In: The Joumal of Psychology, Vol. 92, pp. 103-108.

WEBB, V.N. 1985. Taalnorme en Afrikaans. 'n Geval van twyfel en vertwyfeling? In: Botha, R.P. en M. Sinclair (Reds). Norme vir taalgebruik, Spil plus No. 10, bls. $42-$ 56. 